\title{
Tropical cyclones over the western north Pacific since the mid-nineteenth century
}

\author{
Hisayuki Kubota, et al. [full author details at the end of the article]
}

Received: 1 June 2020 / Accepted: 6 January 2021/Published online: 5February 2021

(C) The Author(s) 2021

\begin{abstract}
Tropical cyclone (TC) activities over the western North Pacific (WNP) and TC landfall in Japan are investigated by collecting historical TC track data and meteorological observation data starting from the mid-nineteenth century. Historical TC track data and TC best track data are merged over the WNP from 1884 to 2018. The quality of historical TC data is not sufficient to count the TC numbers over the WNP due to the lack of spatial coverage and different TC criteria before the 1950s. We focus on TC landfall in Japan using a combination of TC track data and meteorological data observed at weather stations and lighthouses from 1877 to 2019. A unified TC definition is applied to obtain equivalent quality during the whole analysis period. We identify lower annual TC landfall numbers during the 1970 s to the 2000 s and find other periods have more TC landfall numbers including the nineteenth century. No trend in TC landfall number is detected. TC intensity is estimated by an annual power dissipation index (APDI). High APDI periods are found to be around 1900, in the 1910s, from the 1930s to 1960s, and after the 1990s. When we focus on the period from 1977 to 2019, a significant increasing trend of ADPI is seen, and significant northeastward shift of TC landfall location is detected. On the other hand, TC landfall location shifts northeastward and then southwestward in about 100-year interval. European and US ships sailed through East and Southeast Asian waters before the weather station network was established in the late nineteenth century. Then, we focus on TC events in July 1853 observed by the US Naval Japan Expedition of Perry's fleet and August 1863 by a UK Navy ship that participated in two wars in Japan. A TC moved slowly westward over the East China Sea south of the Okinawa Islands from 21 to 25 July 1853. Another TC was detected in the East China Sea on 15-16 August 1863 during the bombardment of Kagoshima in southern Japan. Pressure data are evaluated by comparing the observations made by 10 naval ships in Yokohama, central Japan during 1863-1864. The deviation of each ship pressure data from the 10 ships mean is about $2.7-2.8 \mathrm{hPa}$.
\end{abstract}

Keywords Tropical cyclone $\cdot$ Nineteenth century $\cdot$ Western North Pacific $\cdot$ Data rescue $\cdot$ ACRE

This article is part of the topical collection on "Historical and recent change in extreme climate over East Asia", edited by Guoyu Ren, Danny Harvey, Johnny Chan, Hisayuki Kubota, Zhongshi Zhang, Jinbaso Li 


\section{Introduction}

Tropical cyclone (TC) impacts are one of the most severe disasters to affect western North Pacific (WNP) countries, due to strong wind, heavy rain, and storm surges. Before instrumental meteorological observations were conducted routinely, the awareness of TCs was recorded in various documents (Garciá-Herrera et al. 2007; Chan et al. 2012). Meteorological instruments were invented by G. Galilei (thermometer) and E. Torricelli (barometer) in the seventeenth century and expanded to East and Southeast Asia in the nineteenth century. One of the earliest systematic meteorological observation series recorded was published in the newspaper the Canton Register from 1830 (MacKeown 2010; Tsukahara 2013).

On 27 September 1865, a TC passage was recorded by the instruments at the Manila Central Observatory in the Philippines by Spanish Jesuits missionaries (Deppermann 1939; Udías 1996). From 1873, meteorological observations were shared by telegraph within Hong Kong and Shanghai in China and Nagasaki in Japan. Such observational data were also posted twice daily at ports in the region, and reported in the publication of China Coast Meteorological Register. TCs were traced using these observed weather data. TC tracks in the WNP were recorded by five agencies, namely, Hong Kong Observatory (HKO), Manila Central Observatory, Deutshe Seewarte, Zikawei Observatory, and Central Meteorological Observatory Japan (CMOJ), which is the predecessor of the Japan Meteorological Agency (JMA) from the 1880s (Visher 1925; Kubota 2012).

All of the TC track data in the region were later compiled and reported in various documents and books. From 1977, TCs all over the open ocean could be detected by geostationary satellites, without missing any storms. With TC best track datasets now being regularly distributed online, historical TC track data have often been forgotten. With growing concern about climate change and its projected impacts, the requirement for longer TC data extending back more than 100 years has become an important component in the increasing demand for the recovery of all historical weather observations. Since 2007, the international Atmospheric Circulation Reconstructions over the Earth (ACRE) initiative (Allan et al. 2011) has become a major player in the recovery of historical terrestrial and marine weather data.

Over the Atlantic basin, the historical hurricane track database (HURDAT2) has accumulated TC data extending back to 1851 (Landsea and Franklin 2013). Over the WNP, TC track data reported by the Manila Central Observatory, HKO, Zikawei Observatory, and CMOJ since 1884 were recovered and digitized by the lead author of this paper (Kubota and Chan 2009; Kubota 2012). The International Best Track Archive for Climate Stewardship (IBTrACS) includes TC track data called "” (National Climate Data Center 1973; Knapp et al. 2010). TD 9636 was created by using other TC data sources mentioned above since 1884 .

Meteorological data rescues over Asia are conducted by ACRE Japan, which is one of the regional branches of the ACRE (Williamson et al. 2018; http://www.met-acre.net/chapters. $\mathrm{htm}$ ). Daily rainfall data have been recovered back to the late-nineteenth century in Japan (Fujibe et al. 2005), Philippines (Akasaka et al. 2007; Villafuerte et al. 2014; Kubota et al. 2017), Myanmar (Inoue et al. 2018), Bangladesh (Kiguchi et al. 2018), Cherrapunji of India (Murata et al. 2017), Indonesia (Hamada et al. 2002), and Palau (Kubota et al. 2011) for studying of Asian monsoon variabilities. Historical temperature data have been recovered in Japan from the 1890s for urbanization studies (Fujibe 1995, 1997). Surface pressure data have been recovered for studying of climatic variability in the Pacific-Japan pattern from the 1890s, especially for examining a dominant summer monsoon mode (Kubota et al. 2016). Meteorological data and TC track data are part of the global dataset of the International Surface 
Pressure Databank (ISPD) (Cram et al. 2015) and the NOAA-CIRES-DOE Twentieth Century Reanalysis (20CR) (Slivinski et al. 2019). Utilizing meteorological station data and TC track data for TC landfalls for the past 100 years, plus case studies of past TC landfalls before 1950, several studies investigated TC characteristics in the Philippines (Kubota and Chan 2009; Kubota 2018a) and Japan (Ninomiya 2013; Kumazawa et al. 2016; Fujibe 2018, 2019; Fujibe et al. 2020). These climate variability studies have analyzed over the 100 years, although most of the them have been limited to the twentieth century.

In this study, we focus on TC data over the WNP stating from the mid-nineteenth century. TC landfall data in Japan are extended back to 1877 by using newly recovered meteorological data observed by lighthouses (Zaiki et al. 2018). In East and Southeast Asian regions, meteorological weather stations started observations during the 1860 s to the 1870 s. However, the spatial range of these weather data is limited. Here, we focus on ship log weather records made on vessels sailing through East and Southeast Asian waters. Such ship logs with weather observations from the late-eighteenth century were found in European and US libraries and archives (Brohan et al. 2009). In this study, we collected logs from the ships of the US Naval Japan Expedition of Admiral Perry's fleet, called the "Black ships" in Japan, which came to Tokyo Bay in Japan to open the country to the wider world in the 1850s (Figs. 1, 2a, 6). We also collected similar weather data from UK Navy ships, which came to Japan to take part in two wars that involved the bombardment of Kagoshima, southern Japan in 1863 and Shimonoseki, western Japan in 1864 (Figs. 1, 2b). During 1863-1864, 11 UK Navy ships stayed in Japan. We focus on the TCs observed by these US and UK Navy ships in the East China Sea during July 1853 and August 1863.

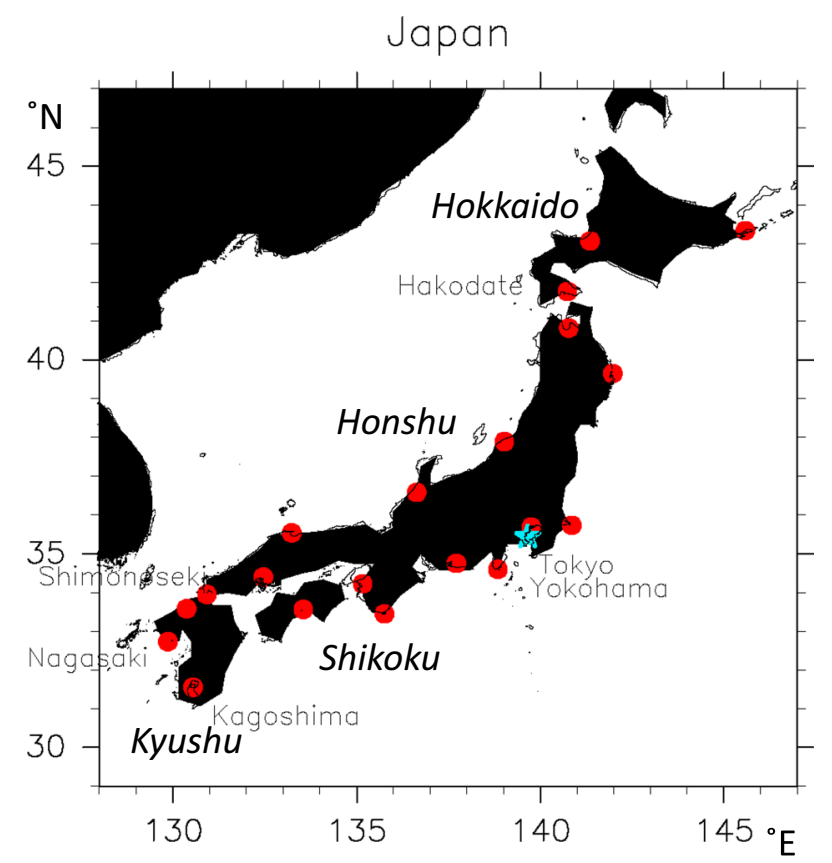

Fig. 1 Four major Islands (Honshu, Hokkaido, Kyushu, and Shikoku) in Japan (shaded in black). Also shown are CMOJ weather stations in 1882 (red dots) and locations of Yokohama (skyblue star), Hakodate, Tokyo, Simonoseki, and Kagoshima 
a

\begin{tabular}{|l|l|l|l|l|}
\hline & 1852 & 1853 & 1854 & 1855 \\
\hline Lexington & & & & \\
\hline Macedonian & & & & \\
\hline Mississippi & & & \\
\hline Plymouth & & & \\
\hline Powhattan & & & \\
\hline Saratoga & & & \\
\hline Southampton & & & \\
\hline Supply & & & \\
\hline Susquehanna & & & \\
\hline Vandalia & & & \\
\hline
\end{tabular}

b

\begin{tabular}{|l|l|l|r|r|}
\hline & 1862 & 1863 & 1864 & 1865 \\
\hline Argus & & & & \\
\hline Barrosa & & & & \\
\hline Coquette & & & & \\
\hline Cormorant & & & & \\
\hline Euryalus & & & & \\
\hline Leopard & & & & \\
\hline Pearl & & & & \\
\hline Perseus & & & & \\
\hline Racehorse & & & & \\
\hline Tartar & & & & \\
\hline Havoc & & & & \\
\hline
\end{tabular}

Fig. 2 Ten fleets of Perry's US Naval Japan Expedition logbooks from 1852 to 1855 (arrows) (a). The fleets came to Japan in July 1853 (red bars) and February to June 1854 (blue bars) (a). Eleven UK Navy ships logbooks from 1862 to 1865 (arrows) (b). They participated in two wars in Japan in August 1863 (orange bars) and September 1864 (red bars) (b)

In Section 2, we introduce TC track data from the mid-nineteenth century over the WNP, meteorological observations recorded by weather stations and lighthouses in Japan, and US and UK Navy ship logbook weather records. In Section 3, we analyze long-term variability of TC numbers from 1884 to 2018 over the WNP and TC landfall in Japan from 1877 to 2019. Case studies of TC tracks in 1853 and 1863 are conducted and evaluated using pressure data observed by UK Navy ships in Section 4. Summary and discussion are given in Section 5.

\section{Data}

\subsection{TC track data}

Historical TC track data over the WNP are listed in Table 1. The domain for WNP $\mathrm{TC}$ covers an area north of the equator, east of $100^{\circ} \mathrm{E}$ and west of the dateline. Historical TC tracks were used by the following agencies, HKO, Manila Central Observatory, Zikawei Observatory, and CMOJ. We merged historical TC data and TC best track data to create long-term TC data (Appendix A). Present TC best track data from the Regional Specialized Meteorological Center (RSMC) Tokyo, Joint Typhoon Warning Center (JTWC), HKO and Shanghai Typhoon Institute (STI) have adopted maximum wind speed of $35 \mathrm{kt}$ for their TC definition. On the other hand, historical TC data used less than $750 \mathrm{mmHg}$ of center pressure in the Monthly Bulletins of the Philippine Weather Bureau (MBP) and $32 \mathrm{kt}$ or $64 \mathrm{kt}$ of wind speed at the HKO. However, other historical TC data did not have TC definitions. 


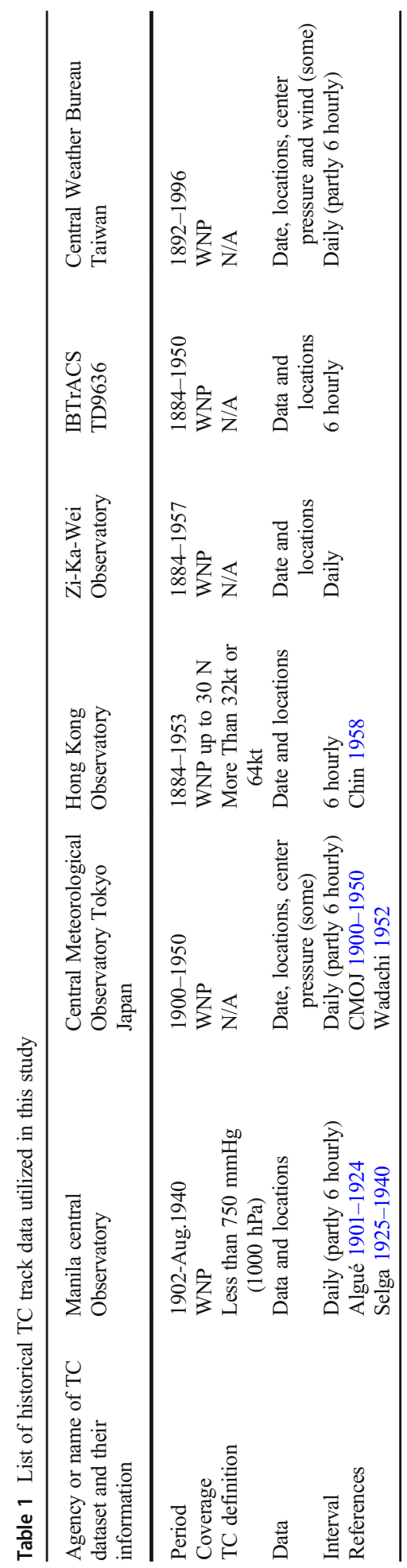




\subsection{Station data in Japan}

Official CMOJ (until 1887 Tokyo Meteorological Observatory) weather station was first established in Hakodate (Fig. 1) in 1872. Numbers of weather stations in Japan from 1873 to 2019 are shown in Fig. B1. During the nineteenth century, lighthouse weather observations in Japan were used to reinforce the number of stations from 1877 to 1885 (Zaiki et al. 2018). Detail of weather station and lighthouse data are described in Appendix B. Local time (LT) in Japan is $9 \mathrm{~h}$ ahead of the Universal Standard Time (UTC).

\subsection{TC landfall data in Japan}

TC landfall is defined as the time when a TC landed on the major four islands (Honshu, Hokkaido, Kyushu, and Shikoku) of Japan (black part in Fig. 1). The criteria for TC landfall are the time when the nearest weather station measured sea level pressure less than $1000 \mathrm{hPa}$ and the left/right side of the landfall point with relation to a weather station measured anticlockwise/clockwise wind direction change during its passage. Detailed definition is described in Appendix C. TC landfalls in Japan from 1877 to 2019 are analyzed (data available at https://jcdp.jp/reconstructed-typhoondata/. Accessed 18 Jan. 2021). Annual TC intensity is calculated by the annual power dissipation index (APDI) (Liu and Chan 2017). The APDI is the sum of each TC landfall intensity defined by the cube of maximum wind speed during landfall. Maximum wind speed is converted from minimum pressure using the pressure-wind relationship (Atkinson and Holliday 1977).

\subsection{Meteorological data in ship logbooks}

Ten fleets of Perry's US Naval Japan Expedition logbooks from 1852 to 1855 are found in the US National Archives. Four fleets came to Tokyo Bay, Japan in July 1853; and nine fleets came to Tokyo from February to June 1854 (Figs. 1, 2a). The locations of the ships and meteorological data were reported in the logbooks. Eleven UK Navy ships participated in two wars of the bombardment of Kagoshima in August 1863 and Shimonoseki in September 1864 (Figs. 1, 2b). The UK Navy ship logbooks are found at the UK Hydrographic Office, the UK National Archives and the National Meteorological Archives of the UK Met Office. Detail of ship logbooks of US and UK Navy ships utilized in this study are described in Appendix D. While sailing, local time of each day was adjusted by sun's culmination at noon (Wallbrink et al. 2009).

\section{Long-term variability of TC numbers}

\subsection{TCs over the WNP}

Annual TC numbers over the WNP from 1884 to 2018 are plotted in Fig. 3. Historical TC data and TC best track data are merged to create long-term TC data. Details of five TC data (Philippines, Hong Kong, Shanghai, Japan, and IBTrACS) are indicated in Appendix A. After the 1950s, the TC numbers of the four agencies show consistent variability. However, discrepancies existed among the agencies before the 1950s. In the 1950s, Hong Kong and Philippines TC numbers were lower compared to the others. In the 1940s, IBTrACS TD9636 have high TC numbers. Before 1940, the Japan TC numbers were lower because the CMOJ focused only on the TCs approaching Japan. Before the 1910s, all the TC decreased the 


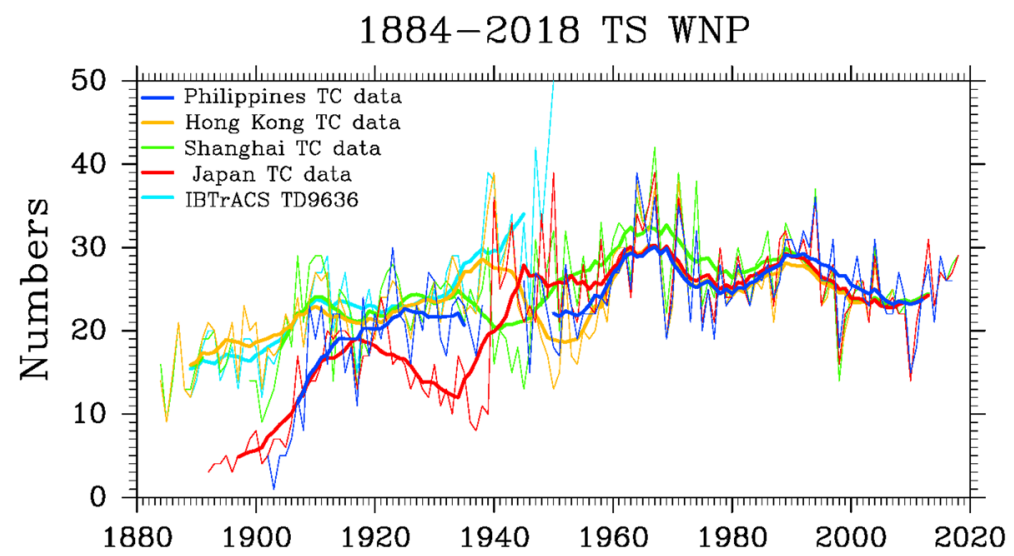

Fig. 3 Annual TC numbers over the WNP from 1884 to 2018 . TC data are merged using historical data and best track data: Philippines TC data (blue), Hong Kong TC data (orange), Shanghai TC data (green), Japan TC data (red) and IBTrACS TD9636 (sky blue). Thick lines are 11-year running means

numbers due to the lack of the area coverage over the eastern part of the WNP. TC numbers were higher in the 1960s and around 1990. And TCs numbers were high around 1910, except for the Japan TC data. Although, the numbers were different, interdecadal variability of TC numbers can be seen in all the datasets. The mechanisms for interdecadal variability of TC numbers after the 1950s are explained by the variability of sea surface temperature, WNP subtropical high, and Pacific Decadal Oscillation (Yumoto and Matsuura 2001; Chan 2005; Liu and Chan 2008). We obtained historical TC data back to 1884; however, we need to examine the reliability of TC numbers to investigate the interdecadal variability before the 1950 s in future study.

\subsection{TC landfall in Japan}

Historical TC track data have discrepancies amongst the datasets before the 1950s. In this subsection, we utilize a combination of TC track data and meteorological data observed at weather stations and lighthouses over land, with a focus on TC landfalls in Japan. Annual TC landfall numbers in Japan from 1877 to 2019 are plotted in Fig. 4a. Mean numbers of TC landfalls are 3.09 per year. Maximum TC landfall number reached 10 in 1950. No TC landfalls were observed in 1973, 1984, 2000, and 2008: and lower than mean TC landfall numbers appeared during the 1970s to the 2000s in the 11-year running mean. On the other hand, at least four TCs landed each year from 2013. Above average TC landfall numbers can be seen from the 1880 s to the 1960 s, except for the late 1870 s to the early-1880s and in the early-1930s. The period from the 1970 s to the early 1980s was the lowest TC landfall periods during the past 140 years. Interdecadal variability of TC landfall in Japan is seen, which will be discussed further in the discussion section. No clear TC landfall trend is seen during the whole period.

Figure $4 \mathrm{~b}$ shows the annual intensity of TC landfall accumulated by the annual power dissipation index (APDI). Mean APDI is $9.09 \times 10^{5}\left(\mathrm{kt}^{3}\right)$ per year. High APDI periods are seen around 1900, and in the 1910s, from the 1930s to the 1960s and after the 1990s. When we focus on the period from 1977 to 2019, a significant increasing trend of APDI can be seen at the $99 \%$ confidence level. Significant test is conducted by Mann-Kendall rank statistic 

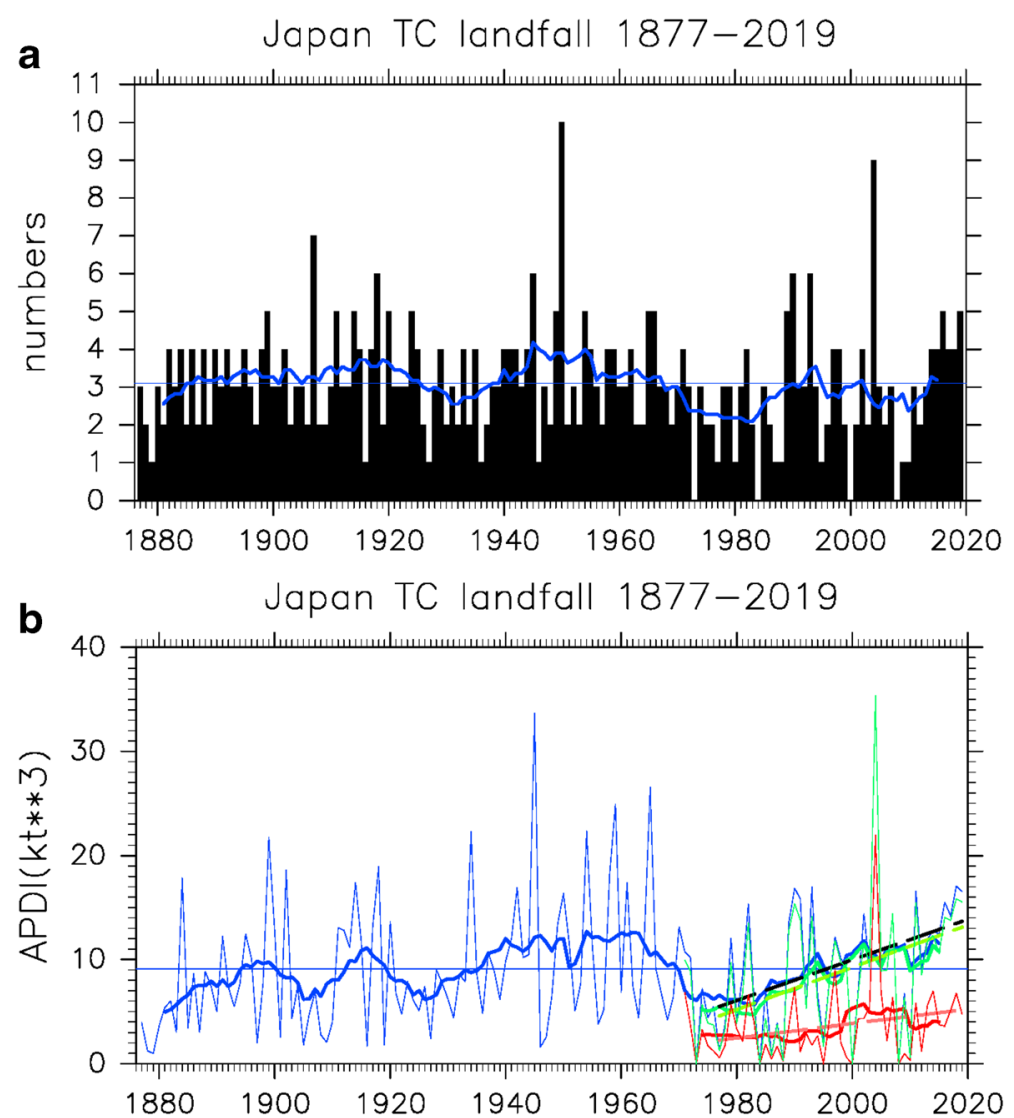

Fig. 4 Annual TC landfall numbers in Japan from 1877 to 2019 (bold bar) (a). Annual power dissipation index (APDI) for TC landfall in Japan from 1877 to 2019 (thin blue line) (b). Pressure data used for APDI is based on hourly data (green line) and condition of 1882 (12 hourly data of 20 stations) (red line). APDI is divided by $10 * * 5$. Black, green, and red dashed lines represent linear trend during 1977-2019, respectively. Significant test is conducted by Mann-Kendall rank statistic. Annual mean during the whole period is described by thin blue line, and values are 3.09 (a) and 9.09 (b), respectively. Thick lines are 11-year running means

(Kendall 1938). Estimated maximum wind speed increased by $37 \%$ during the 43 years. The increasing trend during 1977-2019 is verified by the reduced interval of pressure observations and the number of stations. The ADPI using hourly pressure observations showed consistent significant increasing trend of maximum wind speed by about $42 \%$ at the $99 \%$ confidence level during 1977-2019. When we reduced the number of weather stations to 20 and interval of pressure observations to 12 hourly, we obtained consistent significant increasing trend at the 99\% confidence level, although the magnitude is approximately one third of using all pressure observations. Maximum wind speed increased by $32 \%$ during the 43 years. Twenty weather stations and 12 hourly observation were available in 1882 (Fig. 1). On the other hand, we may question whether increasing trend seen during 1977-2019 is a monotonic increase or part of the fluctuation in the interdecadal variability. We will discuss this using on our long-term data in the discussion section.

Figure 5 shows the longitude (a) and latitude (b) of the nearest weather station during TC landfall in Japan from 1877 to 2019 . The mean location is $\left(135.51^{\circ} \mathrm{E} 34.26^{\circ} \mathrm{N}\right)$. Eastward shift 


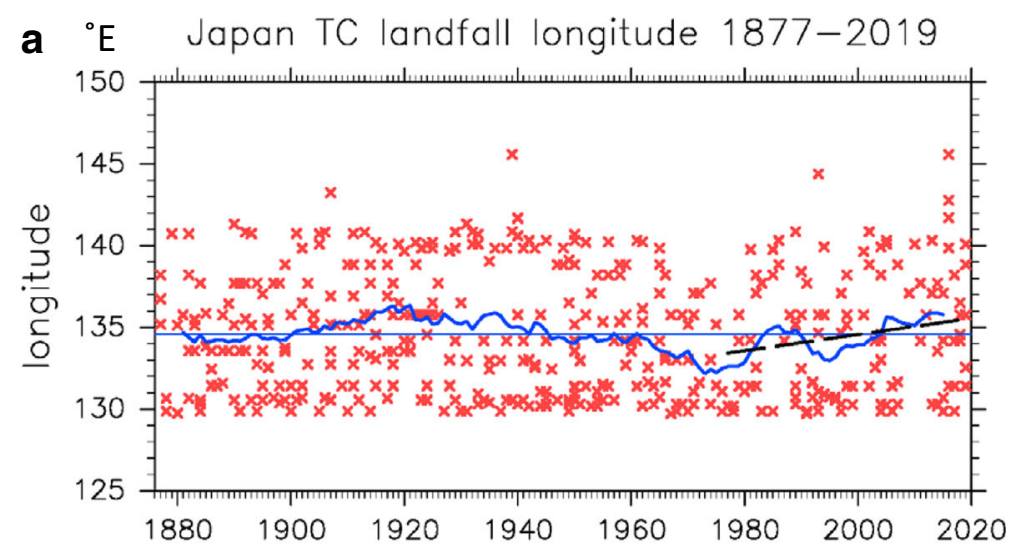

b ${ }^{\circ} \mathrm{N}$ Japan TC landfall latitude 1877-2019

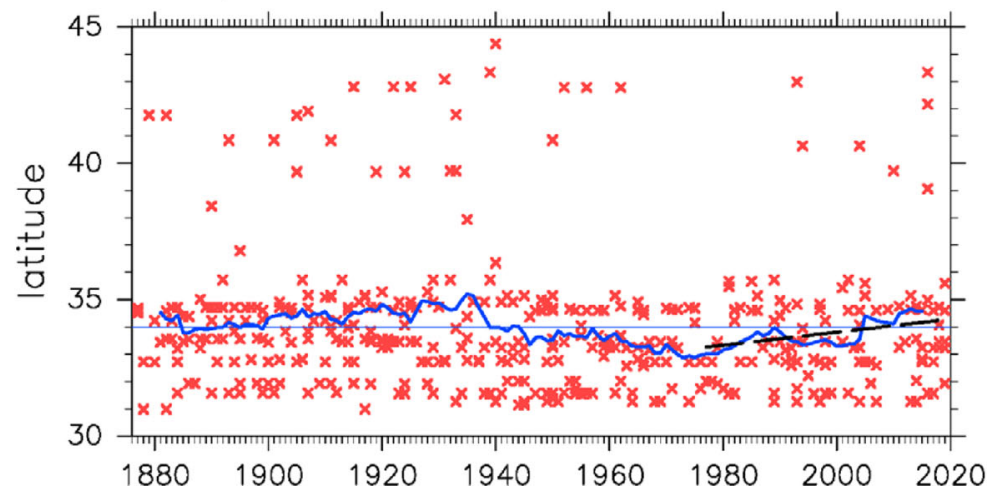

Fig. 5 Longitude (a) and latitude (b) of nearest station during TC landfall in Japan. Thin blue line is the mean location at $\left(134.59^{\circ} \mathrm{E}, 33.99^{\circ} \mathrm{N}\right)$ during the whole period respectively. Thick lines are 11-year running means. Black dashed lines represent linear trend during 1977-2019

of the nearest station to TC landfall location can be seen in the 1920s and after the 2000s, while a northward shift in the 1910 s to the 1930 s and after the 2000s can be detected. On the other hand, the location of TC landfall shifted southwestward during the 1970s. It seems that a northeastward and southwestward shift of TC landfall location has a fluctuation around 100year period. When we focus on the period during 1977-2019, eastward and northward trends of the TC landfall location are seen, which is significant at the $99 \%$ confidence level. This indicates that recent TC landfall locations in Japan tend to shift northeastward in Japan. It may be influenced by atmospheric circulation conditions over the WNP during 1977-2019 (Liu and Chan 2019). However, the increasing tendency during 1977-2019 seems that it includes within a fluctuation in the 100-year time scale variability from our 143 years data analysis.

\section{TC observed by navy ships in the mid-nineteenth century}

Because the spatial coverage of weather stations in Japan before 1877 was limited, we are not able to expand our analysis period of counting TC landfall further back in time. In the East and Southeast Asian regions, there were very few meteorological weather stations before the $1860 \mathrm{~s}$ 


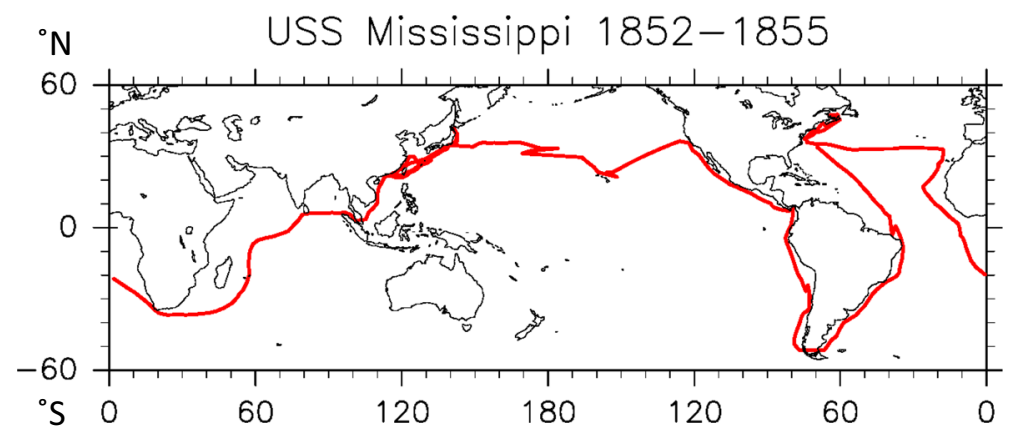

Fig. 6 Ship track of USS Mississippi from 11 May 1852 to 26 April 1855. Adopted from Kubota (2018b)

(Zaiki et al. 2006; Tsukahara 2013). On the other hand, European and US ships sailed through East and Southeast Asia waters and recorded instrumental meteorological data in their logbooks during the nineteenth century. Here, we focus on two case studies of the TCs observed by US and UK Navy ships in that period.

\subsection{TC in July 1853}

One of the ships of the US Naval Japan Expedition, USS (United States Ship) Mississippi, sailed eastward from the east coast of the US, passing through the Atlantic Ocean, around the Cape of Good Hope, and through the Indian Ocean, reaching Tokyo Bay in Japan on 8 July 1853 in order to open up the country of Japan (Figs. 1, 6). However, negotiations were continued into the following year. The ship left Tokyo Bay on 11 July 1853, and stayed in Hong Kong. In 1854, the USS Mississippi came from Hong Kong to Japan again on 11 February. The treaty of peace and amity between Japan and the US was concluded. The USS Mississippi left Japan on 25 June 1854, visiting Hong Kong and Macao; it then sailed eastward, passing Hawaii, through the Strait of Magellan and returned to the east coast of the US in 1855. Two TCs were observed during the cruise in East and South East Asia in July 1853 and October 1854 (Redfield 1856). Here, we focus on the TC in July 1853 (Fig. 7a). Four US Navy ships sailed from Tokyo: the destination of the USS Saratoga was Shanghai, while the other three were bound for Naha in the Okinawa Islands. USS Supply stayed in Naha on July 1853, and measured a pressure drop and rise associated with a TC passage from 20 to 24 July 1853 (Fig. 7b). The US store ship Caprice was sailing in the East China Sea during the same period (pink line of Fig. 7a). Based on meteorological observations of pressure, wind direction and wind force recorded by the five US Navy ships and the US store ship Caprice, a TC track was estimated from 21 to 25 July (red dashed line of Fig. 7a). The TC moved westward very slowly at about $7-12 \mathrm{~km} / \mathrm{h}$. A minimum pressure of $973 \mathrm{hPa}$ was observed in Naha at 15:00 LT (local time) on 22 July by the USS Supply when the TC passed by close to the Okinawa Islands (Fig. 7b). On the same day, the Russian Navy ship Pallada recorded a minimum pressure of $962 \mathrm{hPa}$ in the East China Sea during the Japan Expedition reports (Goncharov 1941). This TC was written in the Russian Julian calendar as being on 9 July, but its location was not reported. The US store ship Caprice measured minimum pressure of $988 \mathrm{hPa}$ at noon LT, and the USS Saratoga measured minimum pressure of $999 \mathrm{hPa}$ at 18:00 LT on 24 July. The TC passed by south of the US store ship Caprice and USS Saratoga, and progressed westward to the China coast. 

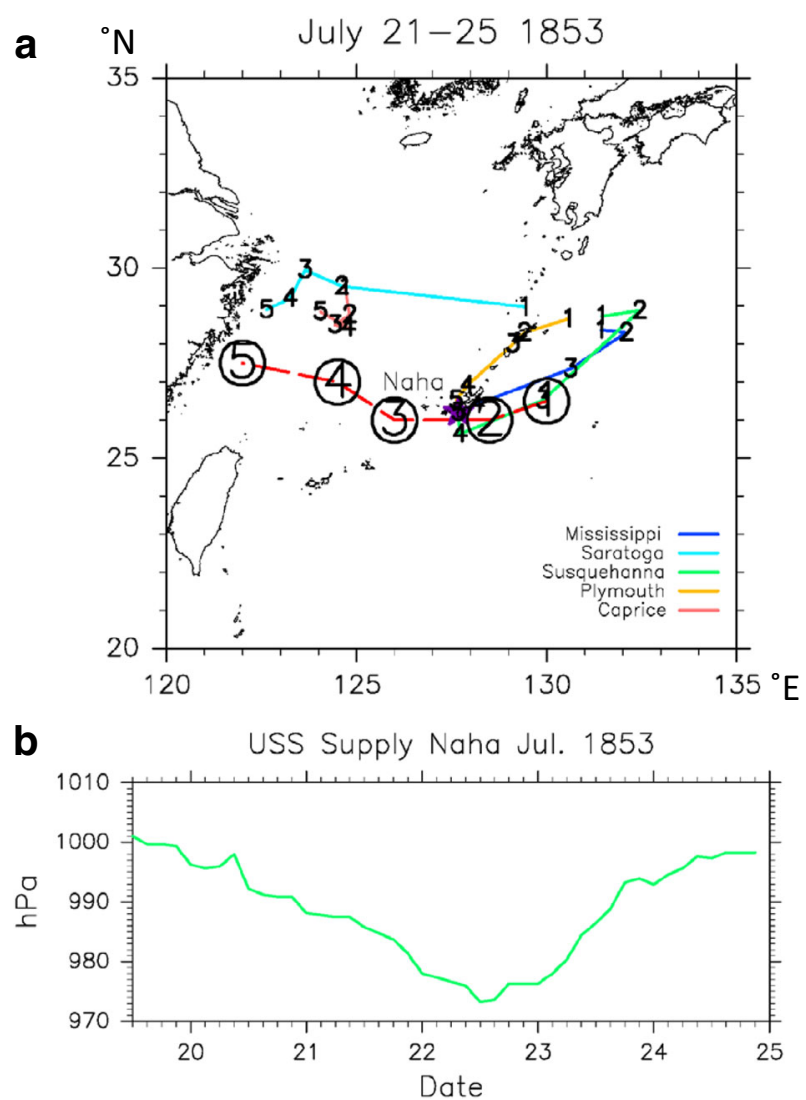

Fig. 7 Estimated TC track (red dashed line) and ship tracks (color lines) during 21-25 July 1853 (a). Numbers indicate the date and location of TC and ship at noon. "1" means " 21 " July. USS supply stayed in Naha [purple star in (a)] and pressure data in (b)

\subsection{TC in August 1863}

After Japan opened the country to the world, many visitors came to Japan from 1854 onwards. A British man was killed in Yokohama, Japan in 1862, in the so-called "Namamugi Incident" by Satsuma (old name of Kagoshima) soldier. The friction between UK and Kagoshima of Japan became worse and a bombardment of Kagoshima occurred in the period from 15 to 17 August 1863. Seven UK Navy ships participated in the war and six of the ships weather data in the logbooks were collected (Fig. 2b). During the battle, a TC passed by northward at west of Kagoshima (Fig. 8). This TC was found by Cary Mock of the University of Carolina (personal communication). The minimum pressure was observed in Kagoshima around 4:00 LT on 16 August 1863 (Table 2). The wind direction changed clockwise from east to south, and the wind force reached up to 9 to 10 of the Beaufort scale around midnight and 4:00 LT on 16 August (not shown) by all the UK Navy ships in Kagoshima. HMS (Her Majesty's Ship) Barrosa first observed a minimum pressure of $996 \mathrm{hPa}$ to the west of the Okinawa Islands at 4:00 LT on 15 August. The wind direction changed anticlockwise, and the wind force reached 8 of the Beaufort scale of northeasterly wind at midnight on 15 August (not shown). The TC passed by east of HMS Barrosa 


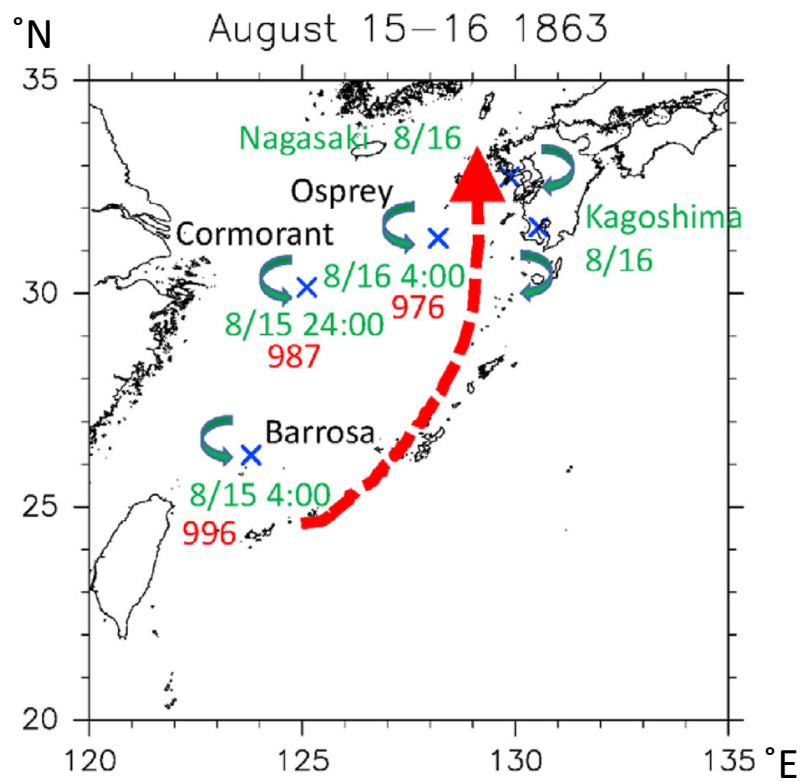

Fig. 8 Estimated TC track during 15-16 August 1863 (red dashed arrow). Blue crosses indicate the locations of ships, Nagasaki and Kagoshima. Green numbers represent date and local time when minimum pressure (red numbers of unit $\mathrm{hPa}$ ) observed. Green arrows show wind direction change

moved northward and passed by closely to the east of HMS Osprey. HMS Osprey observed the lowest pressure of $976 \mathrm{hPa}$ among the UK Navy ships at 4:00 LT on 16 August. The TC passed through between HMS Osprey and Kagoshima, moved northward and passed by west of Nagasaki. HMS Leopard and HMS Rattler observed minimum pressure in Nagasaki between 6:00 and 8:00 LT on 16 August (Table 2). HMS Rattler observed a wind force up to 11 of the Beaufort scale from the southsouthwest wind at noon LT on 16 August (not shown). In summary, a TC was detected by 11 UK Navy ships, which moved northward to the west of the Okinawa Islands on the morning of 15 August 1863, and passed by to the west of Nagasaki on the following morning of 16 August. This TC passage may have influenced outcome of the battle in Kagoshima.

Table 2 Minimum pressure, its observed local time, and wind direction change at the ships during the TC passage at Nagasaki and Kagoshima in 1863

\begin{tabular}{llllll}
\hline Ship & Location & Date & Hour & Minimum pressure & Wind direction change \\
\hline Leopard & Nagasaki & Aug. 16 & $6: 00$ & 985.4 & Clockwise \\
Rattler & Nagasaki & Aug. 16 & $8: 00$ & 987.4 & Clockwise \\
Coquette & Kagoshima & & & No data & Clockwise \\
Euryalus & Kagoshima & Aug. 16 & $4: 00$ & 990.1 & Clockwise \\
Havoc & Kagoshima & & & No Data & Clockwise \\
Pearl & Kagoshima & Aug. 15-16 & $23: 00-6: 00$ & 992.2 & Clockwise \\
Perseus & Kagoshima & Aug. 16 & $4: 00$ & 983.7 & Clockwise \\
Racehorse & Kagoshima & Aug. 16 & $4: 00$ & 992.2 & Clockwise \\
\hline
\end{tabular}




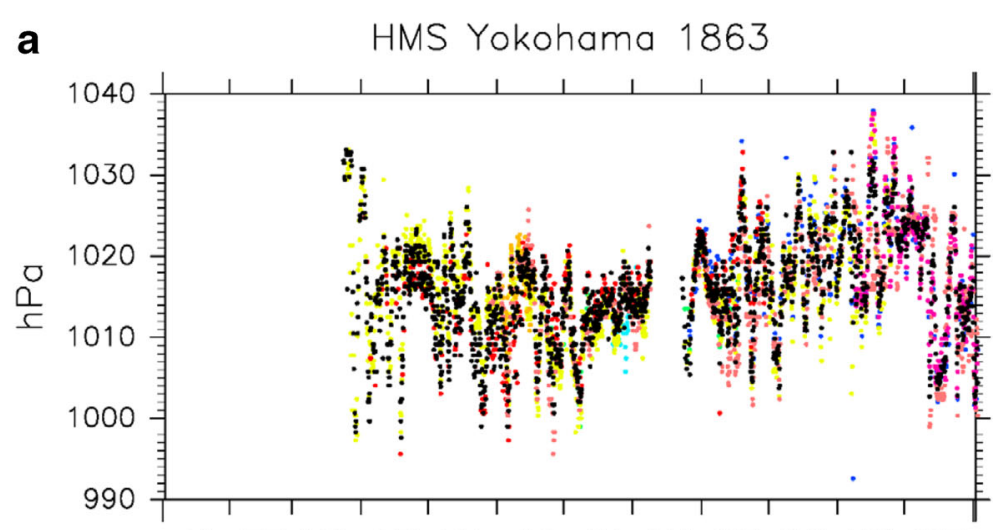

JA FE MA AP MA JU JU AU SE OC NO DE

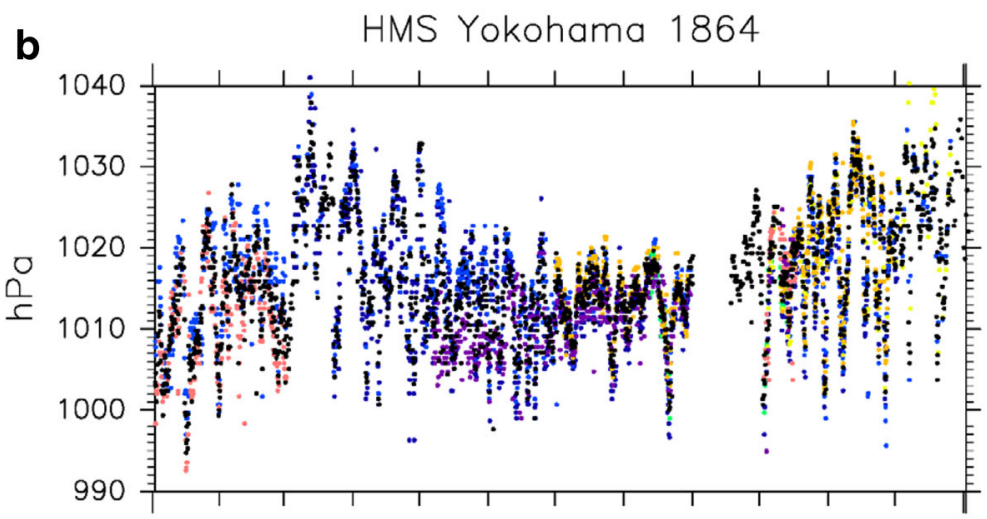

JA FE MA AP MA JU JU AU SE OC NO DE

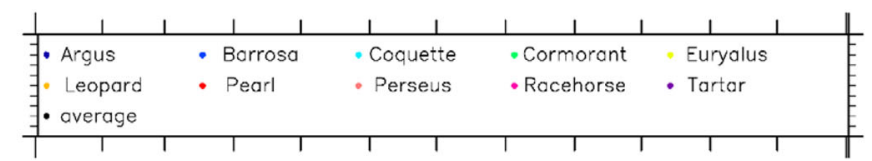

Fig. 9 Pressure data observed in Yokohama by UK Navy ships in 1863 (a) and 1864 (b). Black dots are mean pressure value at each local time

\subsection{Pressure data in Yokohama in 1863 and 1864}

UK Navy ships participated in the two wars in Japan, the bombardment of Kagoshima in August 1863 and in Shimonoseki in September 1864. During 1863-1864, UK Navy ships stayed around Japan. The Japanese government opened a few ports, including Yokohama (Fig. 1 ) in the 1860s. Figure 9 shows pressure data in Yokohama during 1863-1864 observed by 10 UK Navy ships. Naval ships continued their meteorological observations even while they were anchored at port. Mean pressure data at each local time are plotted as black dots. Pressure data are available from the end of March 1863 to December 1864. Pressure data are evaluated by comparing multiple ships' observations. The numbers of observations, bias and standard deviation of each ship compared to the mean pressure data are listed in Table S1. When more than two ships made observations at the same time, we count the numbers as observations. The range of the difference between ships is about 2.7-2.8 $\mathrm{hPa}$ from $-1.57 \mathrm{hPa}$ of HMS Coquette 
to $1.24 \mathrm{hPa}$ of HMS Leopard in 1863 and from $-1.79 \mathrm{hPa}$ of HMS Tartar to 0.87 of HMS Barrosa in 1864 based on bais of Table S1. HMS Barrosa and HMS Leopard tended to measure higher pressure than the mean; and HMS Perseus tended to measure lower values in both years. On the other hand, HMS Cormorant and HMS Euryalus had small biases in both years. These tendencies are consistent with the observations in Kagoshima on 16 August 1863 (Table 2). The pressure data are not adjusted to sea level by all ships. HMS Euryalus had a correction report of pressure data from 1 April 1862 to 14 February 1863 stored in the National Meteorological Archives of the UK Met Office. When we applied this value, the corrected pressure data of HMS Euryalus became $990.6 \mathrm{hPa}$ in Kagoshima on 4:00 LT 16 August. The height of barometer of HMS Euryalus was $18 \mathrm{ft}$. from the sea surface. French naval doctor P. Mourier observed weather four times a day on 7:00, 10:00, 16:00, and 22:00 LT in Yokohama from December 1864 (Zaiki et al. 2006). Pressure data were adjusted to sea level. During December 1864, only HMS Barrosa observed at the same local times as Mourier's observations. The difference between Mourier's observation and HMS Barrosa showed $0.44 \mathrm{hPa}$ higher by HMS Barrosa. We subtract the bias of HMS Barrosa 0.87, and applied ship height adjustment to sea level in the same way as of HMS Euryalus. Several disturbances of low pressures and strong winds were also observed in Yokohama on 19 August and again on 30 September 1864 associated with a TC passage (not shown). Further analysis of such TCs is needed in future studies.

\section{Summary and discussion}

\subsection{Summary}

In this study, we investigate TC activities over the WNP and TC landfall in Japan during the nineteenth century by analyzing historical TC track data and meteorological observational data. Meteorological observations were obtained from weather stations, lighthouses and US and UK naval ships. We merged the TC data from 1884 to 2018 using historical TC track data and TC best track data over the WNP. However, the quality of historical TC data is not sufficient to count the TC numbers over the WNP due to the lack of spatial coverage and different TC definitions before the 1950s. We then focused on TC landfall in Japan using a combination of TC track data and meteorological data observed at weather stations and lighthouses from 1877 to 2019. A unified TC definition is applied to ensure consistent quality of data during the whole analysis period. TC landfall is defined as the time when the nearest weather station measured sea level pressure less than $1000 \mathrm{hPa}$ and the left/right side of the landfall site, station measured anticlockwise/clockwise wind direction change (Kumazawa et al. 2016). Lower annual TC landfall numbers are found during the 1970 s to the 2000 s, while more TC landfall numbers are seen during the other periods, including the nineteenth century. No trend of TC landfall is detected. TC intensity is estimated by using APDI. High APDI periods are seen around 1900, and in the 1910s, from the 1930s to the 1960s and after the 1990s. When we focus on the period from 1977 to 2019, we detect a significant increasing trend of ADPI even when we reducing the interval of weather observations and the number of weather stations to reproduce the weather station condition in the $1880 \mathrm{~s}$. TC landfall locations shifted northeastward from the 1910 s to the 1930 s and after the 2000s, and shifted southwestward during the 1970s. Northeastward and southwestward shifts of TC landfall location had a fluctuation of 
about 100-year interval. When we focus on the period during 1977 to 2019, we also detect a significant northeastward shift of TC landfall location.

In East and Southeast Asia, meteorological weather stations started collecting observations during the 1860s and 1870s. On the other hand, European and US ships sailed through East and Southeast Asian waters, observing weather using meteorological instruments from the nineteenth century. Here, we focus on TC events before the weather stations were established in East and Southeast Asia in July 1853, which were observed by a US Naval Japan Expedition of Perry's fleet, and on TC event in August 1863 which was observed by a UK Navy ship participated in two wars in Japan, the bombardment of Kagoshima in 1863 and Shimonoseki in 1864. A TC in July 1853 was detected by five US Navy ships and the US store ship Caprice using meteorological observations of pressure, wind direction and wind force. The TC moved slowly westward over the East China Sea to the south of the Okinawa Islands from 21 to 25 July. Another TC was detected in the East China Sea between 15 and 16 of August 1863 during the bombardment of Kagoshima. In total, 11 UK Navy ships were deployed to the East China Sea and in the Kagoshima and Nagasaki regions of Japan. A TC moved northward to the west of the Okinawa Islands in the morning of 15 August 1863, passing by on the west of Kagoshima and reaching the west of Nagasaki on the following morning. During 1863-1864, 10 UK Navy ships anchored in Yokohama. These naval ships continued making meteorological observations even when anchored at port. We evaluate these pressure data by comparing multiple ships' observations in Yokohama. The range of the difference in pressure records between the ships is about 2.7-2.8 hPa. Compared to the land observations conducted by a French naval doctor P. Mourier during December 1864, the pressure taken by HMS Barrosa was higher by $0.44 \mathrm{hPa}$.

\section{Discussion}

The recovery and analysis of historical TC track data can improve our understanding of historical TC activity over East to Southeast Asia in the nineteenth century. TCs left many footprints during their passages. For example, a combination of weather station and lighthouse measurements covered much of the country around Japan all the way back to 1877 . By utilizing alternative TC definition plus using surface meteorological observations, we recovered TC landfalls in Japan for 143 years from 1877 to 2019. Recent studies presented the peak intensity of TC shifted northward over the WNP since the 1980s (Kossin et al. 2014; Sun et al. 2019). Indeed, our analysis shows a significant increasing trend of TC intensity of landfall in Japan from 1977 to 2019. However, these discussions are based on limited period around 40 to 50 years and lack the scope of interdecadal variability of longer time periods. In this study, we utilize 143-year TC data from 1877 to 2019 , and find TC landfall numbers and intensity in Japan have dominant interdecadal variability. Liu et al. (2020) expanded the analysis period from 1910 to 2019 and showed the interdecadal variability of meridional shift of TC tracks between the South China Sea and near Japan. TC frequency near Japan became higher during 1910-1926, 1943-1963, and 1997-2019. This is consistent with the higher TC landfall numbers in Japan (Fig. 4a). Liu et al. (2020) explained the mechanism by using the variability of large-scale environmental flow patterns.

On the other hand, TC landfall location has a fluctuation of about 100-year interval. When we use the TC landfall locations in each month, and the 100-year timescale variability is seen only in August (Fig. S1), TC tends to move along the 
western edge of WNP subtropical high. Therefore, the variability of westward extension WNP subtropical high is one of the important mechanisms for interanuual and interdecadal variability of TC tracks (Chan 2005). Nagata and Mikami (2017) showed summer WNP subtropical high tended to shift northwestward during 1900-1950 and southwestward during 1950-2000. It supports our analysis of northwestward shift of TC landfall location in the early half of twentieth century and southwestward shift during the latter half of twentieth century (Fig. 5). We need further discussions on how much the trend obtained in the recent 40-50 years comes from anthropogenic warming.

In this study, we utilize unified TC definition to obtain consistent quality of the data during the analysis period. The quality of TC landfall data depends on the numbers of stations and interval of pressure observations. Numbers of available weather stations in Japan decreased as time goes back past 1940 (Fig. B1). On the other hand, instantaneous pressure data are necessary to identify the signal of TC landfall. Such data are only available from 1900 . Therefore, the quality of TC landfall data is consistent from 1900. However, the data quality became lower in the nineteenth century.

The spatial coverage of meteorological observations is necessary for a viable count of TC number. Before 1876, numbers of meteorological observations were not sufficient in Japan. As a consequence, in this study, we utilize instrumental meteorological records from the logbooks of vessels sailing through East and Southeast Asia in the nineteenth century. Many European and American ships came to China after the Opium War of the 1840s, traveling to Japan after the country opened up to the outside world from the 1850s. Instrumental meteorological records observed by European and US ships are stored in libraries, archives and repositories in each of these countries, but have not been widely utilized. These data have a huge potential for the discovery of unknown historical TC activity in the nineteenth century.

Supplementary Information The online version contains supplementary material available at https://doi.org/ 10.1007/s10584-021-02984-7.

Acknowledgements Hisayuki Kubota, Jun Matsumoto, and Masami Zaiki were supported by Grant-in-Aid for Scientific Research [No. 25282085, 15KK0030 and 18H05307 (PI: HK): No. 20240075, 23240122, 26220202 19H00562; (PI: JM): No. 16H03116 (PI: MZ), No. 18H01278 (PI: Yu Kosaka of the University of Tokyo)] and by the Young Scientific Research No. 21684028, (PI: HK) of the MEXT. Rob Allan is supported by funding from the UK Newton Fund, which is managed by the UK Department for Business, Energy and Industrial Strategy [BEIS], under its CSSP China and WCSSP South Africa projects, plus the EU Copernicus C3S Data Rescue Service. RA also acknowledges the University of Southern Queensland, Toowoomba, Australia, and the Centre for Maritime Historical Studies, University of Exeter, Exeter, UK, where he is an Adjunct and Honorary Professor respectively. The author thanks Dr. Mong-Ming Lu of the Central Weather Bureau, Prof. Chih-Wen Hung of the National Taiwan Normal University, Prof. Chung-Hsiung Sui of the National Taiwan University, Mr. Edwin W. L. Ginn of the Hong Kong Observatory, Dr. Bingke Zhao of the Shanghai Typhoon Institute, the Philippine Atmospheric Geophysical and Astronomical Services Administration, University of Hawaii, and the Japan Meteorological Agency for sharing historical typhoon books. GFD-DENNOU library was used for drawing the figures.

Open Access This article is licensed under a Creative Commons Attribution 4.0 International License, which permits use, sharing, adaptation, distribution and reproduction in any medium or format, as long as you give appropriate credit to the original author(s) and the source, provide a link to the Creative Commons licence, and indicate if changes were made. The images or other third party material in this article are included in the article's Creative Commons licence, unless indicated otherwise in a credit line to the material. If material is not included in the article's Creative Commons licence and your intended use is not permitted by statutory regulation or exceeds the permitted use, you will need to obtain permission directly from the copyright holder. To view a copy of this licence, visit http://creativecommons.org/licenses/by/4.0/. 


\section{References}

Akasaka I, Morishima W, Mikami T (2007) Seasonal march and spatial difference of rainfall in the Philippines. Int J Climatol 27:715-725

Algué RJSJ (1901-1924) Monthly Bulletins of Philippine Weather Bureau. Manila Central Observatory

Allan R, Brohan P, Compo GP, Stone R, Luterbacher J, Brönnimann S (2011) The International Atmospheric Circulation Reconstructions over the Earth (ACRE) initiative. Bull Amer Meteor Soc 92:1421-1425. https:// doi.org/10.1175/2011BAMS3218.1

Atkinson GD, Holliday CR (1977) Tropical cyclone minimum sea level pressure/maximum sustained wind relationship for the western North Pacific. Mon Weather Rev 105:421-427

Brohan P, Allan R, Freeman JE, Waple AM, Wheeler D, Wilkinson C, Woodruff S (2009) Marine observations of old weather. Bull Amer Meteor Soc 90:219-230

Chan JCL (2005) Interannual and interdecadal variations of tropical cyclone activity over the western North Pacific. Meteorog Atmos Phys 89:143-152. https://doi.org/10.1007/s00703-005-0126-y

Chan JCL, Liu KS, Xub M, Yang Q (2012) Variations of frequency of landfalling typhoons in East China, 14501949. Int J Climatol 32:1946-1950

Chin PC (1958) Tropical cyclones in the Western Pacific and China Sea area from 1884 to 1953. Royal Observatory, Hong Kong

CMOJ (1900-1950) Monthly bulletin of CMOJ. Tokyo

Cram TA, Compo GP, Yin X, Allan RJ, McColl C, Vose RS, Whitaker JS, Matsui N, Ashcroft L, Bessemoulin P, Brandsma T, Brohan P, Brunet M, Comeaux J, Crouthamel R, Gleason BE Jr, Groisman PY, Hersbach H, Jones PD, Jónsson T, Jourdain S, Kelly G, Knapp KR, Kocen R, Kruger A, Kubota H, Lentini G, Lorrey A, Lott N, Lubker SJ, Luterbacher J, Marshall GJ, Maugeri M, Mok HY, Nordli Ø, Rodwell MJ, Ross TF, Schuster D, Sima F, Srnec L, Valente MA, Vizi Z, Wang XL, Westcott N, Woollen JS, Worley SJ (2015) The International Surface Pressure Databank version 2. Geosci Data J 2:31-46

Deppermann CESJ (1939) Some characteristics of Philippine typhoons. Weather Bureau, Manila

Fujibe F (1995) Temperature rising trends at Japanese cities during the last hundred years and their relationships with population, population increasing rates and daily temperature ranges. Pap Meteorol Geophys 46:35-55

Fujibe F (1997) Time-of-the-day dependence of long-term temperature changes at urban meteorological stations in Japan. J Meteor Soc Japan 75:1041-1051

Fujibe F (2018) Strong wind and disaster at eastern Japan due to typhoon in Sep. 28, 1902. Tenki 65:691-699 (in Japanese)

Fujibe F (2019) Disaster and strong wind at Kagoshima due to typhoon in Sep. 15 1899. Tenki 66:30-36 (in Japanese)

Fujibe F, Matsumoto J, Kamahori H (2020) A climatological study of heavy rainfalls due to Typhoon Hagibis in 2019, Tenki 67: in printing (in Japanese)

Fujibe F, Yamazaki N, Katsuyama M, Kobayashi K (2005) The increasing trend of intense precipitation in Japan based on four-hourly data for a hundred years. SOLA 1:41-44. https://doi.org/10.2151/sola.2005-012

García-Herrera R, Ribera P, Hernández E, Gimeno L (2007) Northwest Pacific typhoons documented by the Philippine Jesuits, 1566-1900. J Geophys Res 112:D06108. https://doi.org/10.1029/2006JD007370

Goncharov IA (1941) The frigate Pallada. Translated to Japanese by Inoue M. Iwanami Shoten, Tokyo

Hamada JI, Yamanaka MD, Matsumoto J, Fukao S, Winarso PA, Sribimawati T (2002) Spatial and temporal variations of the rainy season over Indonesia and their link to ENSO. J Meteor Soc Japan 80:285-310

Inoue T, Matsumoto J, Kubota H (2018) Long-term variations of precipitation in Myanmar (Burma) for recent 125 years (1891-2015). 11th ACRE workshop

Kendall MG (1938) A new measure of rank correlation. Biometrika 30:81-93

Kiguchi M, Okami N, Murata F, Tanoue M, Fukushima A, Yamane Y, Terao T, Hayashi T, Oki T, Inoue T, Matsumoto J (2018) Change of rainfall characteristics in Bangladesh using 126-years record. 11th ACRE workshop

Knapp KR, Kruk MC, Levinson DH, Diamond HJ, Neumann CJ (2010) The international best track archive for climate stewardship (IBTrACS) Unifying Tropical cyclone Data. Bull Amer Meteor Soc 91:364-376. https://doi.org/10.1175/2009BAMS2755.1

Kossin JP, Emanuel KA, Vecchi GA (2014) The poleward migration of the location of tropical cyclone maximum intensity. Nature 509:349-352. https://doi.org/10.1038/nature13278

Kubota H (2012) In: Oouchi K, Fudeyasu H (eds) Variability of typhoon tracks and genesis over the Western North Pacific Cyclones, vol 95-114. Formation, Triggers and Control, Nova Science Publishers, Inc.

Kubota H (2018a) Comparison of tropical cyclones Haiyan and Talas with tropical cyclones having similar tracks in the past 120 years. J Geograph (Chigaku Zasshi) 127:471-482 
Kubota H. (2018b) Meteorological records observed by Perry’s fleet during late Edo era. Japan-Asia climate data program. Recent topic https://jcdp.jp/meteorological-records-observed-by-perrys-fleet-during-late-edo-era/

Kubota H, Chan JCL (2009) Interdecadal variability of tropical cyclone landfall in the Philippines from 1902 to 2005. Geophys Res Lett 36:L12802. https://doi.org/10.1029/2009GL038108

Kubota H, Kosaka Y, Xie SP (2016) A 117-year long index of the Pacific-Japan pattern with application to interdecadal variability. Int J Climatol 36:1575-1589

Kubota H, Shirooka R, Hamada JI, Syamsudin F (2011) Interannual rainfall variability over the eastern maritime continent. J Meteor Soc Japan 89A:11-22

Kubota H, Shirooka R, Matsumoto J, Cayanan EO, Hilario FD (2017) Tropical cyclone influence on the longterm variability of Philippine summer monsoon onset. Prog Earth Planet Sci. https://doi.org/10.1186/s40645017-0138-5

Kumazawa R, Fudeyasu H, Kubota H (2016) Tropical cyclone landfall in Japan during 1900-2014. Tenki 63: 855-861

Landsea CW, Franklin JL (2013) Atlantic hurricane database uncertainty and presentation of a new database format. Mon Weather Rev 141:3576-3592

Liu KS, Chan JCL (2008) Interdecadal variability of western North Pacific tropical cyclone tracks. J Clim 21: $4464-4476$

Liu KS, Chan JCL (2017) Variations in the power dissipation index in the East Asia region. Clim Dyn 48:19631985. https://doi.org/10.1007/s00382-016-3185-5

Liu KS, Chan JCL (2019) Interdecadal variation of frequencies of tropical cyclones, intense typhoons and their ratio over the western north Pacific. Int J Climatol. https://doi.org/10.1002/joc.6438

Liu KS, Chan JCL, Kubota H (2020) Meridional oscillation of tropical cyclone activity in the western North Pacific during the past 110 years. Clim Change 164:23 https://doi.org/10.1007/s10584-021-02983-8

MacKeown PK (2010) Early China coast meteorology. Hong Kong University Press

Murata F, Terao T, Fujinami H, Hayashi T, Asada H, Matsumoto J, Syiemlieh HJ (2017) Dominant synoptic disturbance in the extreme rainfall at Cherrapunji, Northeast India, based on 104 years of rainfall data (19022005). J Clim 30:8237-8251. https://doi.org/10.1175/JCLI-D-16-0435.1

Nagata R, Mikami T (2017) Changes in the relationship between summer rainfall over Japan and the North Pacific subtropical high, 1910-2000. Int J Climatol 37:3291-3296. https://doi.org/10.1012/joc.4915

National Climate Data Center (1973) TD 9636 Tropical cyclone documentation manual. National Oceanic and Atmospheric Administration

Ninomiya K (2013) Meteorological condition of the heavy rainfall over the Kii Peninsula accompanied with typhoon in August 19-20, 1889. Tenki 60:261-270

Redfield WC (1856) Observations in the relation to the cyclones of the western Pacific. Narrative of the expedition of an American squadron to the China Seas and Japan, House of Representatives 2:337-359

Selga RMSJ (1925-1940) Monthly Bulletins of Philippine Weather Bureau. Manila Central Observatory

Slivinski LC, Compo GP, Whitaker JS, Sardeshmukh PD, Giese B, McColl C, Brohan P, Allan R, Yin X, Vose R, Titchner H, Kennedy J, Rayner N, Spencer LJ, Ashcroft L, Bronnimann S, Brunet M, Camuffo D, Cornes R, Cram TA, Crouthamel R, Dominguez-Castro F, Freeman JE, Gergis J, Hawkins E, Jones PD, Jourdain S, Kapla A, Kubota H, Blancq FL, Lee TC, Lorrey A, Luterbacher J, Maugeri M, Mock CJ, Moore GWK, Przybylak R, Pudmenzky C, Reason C, Slonosky VC, Smith C, Tinz B, Trewin B, Valente MA, Wang XL, Wilkinson C, Wood K, Wyszynski P (2019) Towards a more reliable historical reanalysis: improvements for version 3 of the twentieth century reanalysis system. Q J Roy Meteor Soc 145:2876-2908. https://doi.org/10. 1002/qj.3598

Sun J, Wang D, Hu X, Ling Z, Wang L (2019) Ongoing poleward migration of tropical cyclone occurrence over the western North Pacific Ocean. Geophys Res Lett 46:9110-9117. https://doi.org/10.1029/2019GL084260

Tsukahara T (2013) 19th century Chinese meteorology: climate reconstruction based on historical record in English newspapers. Historic Geograph Japan 55:69-81

Udías A (1996) Jesuits' contribution to meteorology. Bull Amer Meteor Soc 77:2307-2315

Villafuerte MQ II, Matsumoto J, Akasaka I, Takahashi H, Kubota H, Cinco TA (2014) Long-term trends and variability of rainfall extremes in the Philippines. Atmos Res 137:1-13

Visher SS (1925) Tropical cyclones of the Pacific. Bernice P. Bishop Museum, Bulletin 20, Hawaii

Wadachi (1952) Typhoon tracks 1940-1950. The Central Meteorological Observatory Tokyo Japan, Tokyo

Wallbrink H, Koek F, Brandsma T (2009) The US Maury collection Metadata 1796-1861. HISKLIM11, KNMI publication 225, The Netherlands

Williamson F, Allan R, Ren G, Lee T-C, Lui W, Kubota H, Matsumoto J, Luterbacher J, Wilkinson C, Wood K (2018) Collating historic weather observations for the East Asian region: challenges, solutions, and reanalyses. Adv Atmos Sci 35:899-904. https://doi.org/10.1007/s00376-017-7259-z

Yumoto M, Matsuura T (2001) Interdecadal variability of tropical cyclone activity in the western north Pacific. J Meteor Soc Japan 79:23-35 
Zaiki M, Können GP, Tsukahara T, Mikami T, Matsumoto K, Jones PD (2006) Recovery of 19th century Tokyo/ Osaka meteorological data in Japan. Int J Climatol 26:399-423

Zaiki M, Mikami T, Hirano J, Grossman M, Kubota H, Tsukahara T (2018) Climate characteristics in the Southeastern Kanto region of Japan derived from mid to late 19th century meteorological records. J Geograph (Chigaku Zasshi) 127:447-455

Publisher's note Springer Nature remains neutral with regard to jurisdictional claims in published maps and institutional affiliations.

\section{Affiliations}

\section{Hisayuki Kubota ${ }^{1} \cdot$ Jun Matsumoto ${ }^{2,3} \cdot$ Masumi Zaiki $^{4} \cdot$ Togo Tsukahara $^{5} \cdot$ Takehiko

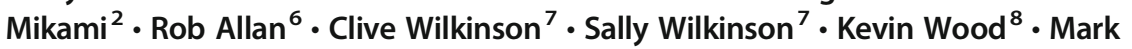 Mollan $^{9}$}

Hisayuki Kubota

hkubota@ep.sci.hokudai.ac.jp

1 Hokkaido University, Kita 10 Nishi 8, Kita-ku, Sapporo, Japan

2 Tokyo Metropolitsan University, Tokyo, Japan

3 Japan Agency for Marine Earth Science and Technology, Yokosuka, Japan

4 Seikei University, Tokyo, Japan

5 Kobe University, Kobe, Japan

6 Met Office, Exeter, UK

7 CSW Associates Data Services, Norwich, UK

8 National Oceanic and Atmospheric Administration, Seattle, USA

9 Naval History and Heritage Command, Washington, D.C., USA 